\title{
Studies on the Durability of Wood-cement Particleboards Produced with Residues of Pinus spp., Silica Fume, and Rice Husk Ash
}

\author{
Adauto José Miranda de Lima, ${ }^{a}$ Setsuo Iwakiri, ${ }^{b}$ Kestur G. Satyanarayana, ${ }^{\mathrm{c}, *}$ and \\ María Guadalupe Lomelí-Ramírez ${ }^{\mathrm{d}}$
}

\begin{abstract}
Wood-cement composites were considered as substitutes for wood or asbestos cement. This research is focused on the development, characterization, and durability of different wood-cement particle boards composed of wood waste [residual particles of pine species (Pinus spp.)], with silica fume or rice husk ash. The wood-cement panels produced by cold compression were evaluated for their physical and mechanical properties after accelerated and natural weathering for 28 and 91 days of curing, respectively. Results indicate that the performance of wood-cement panels containing the Pinus spp. residue was comparable to that of lignocellulosic aggregate in wood cement panels. Pine residue wood panels exhibited high levels of pozzolanic activity, suggesting that silica fume or rice husk ash could be used as a partial substitute in Portland cement. There was a significant loss of mechanical properties over time with both the reference panel and the panel produced with pozzolana. Although there was no direct correlation between the values of accelerated weathering tests and natural weathering tests, there was a larger degradation of the panels after 20 cycles of the accelerated weathering than that after 12 months of natural weathering. Morphology studies supported the observed results.
\end{abstract}

Keywords: Wood-cement particleboards; Pinus spp.; Silica fume; Rice husk ash; Durability; Accelerated weathering

Contact information: a: Academic Department of Civil Construction, Federal University of Technology of Paraná, Rua Dep. Heitor de Alencar Furtado, 4900, Curitiba, Paraná, Brazil; b: Department of Forestry, Engineering, and Technology, Federal University of Paraná, Av. Lothário Meissner, 632, Curitiba, Paraná, Brazil; c: Poornaprajna Institute of Scientific Research, Sy. No. 167, Poornaprajna pura, Bidalur Post, Devanahalli, Bengaluru, Karnataka 562110 India; d: Department of Wood, Cellulose and Paper, University of Guadalajara, Km 15.5 Carretera Guadalajara-Nogales, Las Agujas. Zapopan, Jalisco, México; *Corresponding author: gundsat42@hotmail.com

\section{INTRODUCTION}

Most of the wastes generated by various industries have the potential to return to the production chain, leading to the development of new materials. One such waste is that produced by the timber industry. Brazil is the fifth largest agricultural producer in the world, and according to the latest available survey of the National Forest Information System, 267.69 million $\mathrm{m}^{3}$ of wood were used in the year 2015, generating approximately 1.93 million tons of waste (SNIF 2016). If not used for fuel, it can also end up as discarded material and possibly thrown into landfills. This would undergo biodegradation releasing methane, which is up to 72 times worse than $\mathrm{CO}_{2}$ to the greenhouse effect (Doudart de la Gree et al. 2014). 
There are also other industrial wastes. These include silica fume (SF) and rice husk ash (RHA) that have potential for their value-added uses. The former is a byproduct of the manufacture of silicon metal and other silicon alloys, and the latter is a byproduct of the burning of the rice husk and is typically disposed of inappropriately into the environment (Tashima et al. 2012; Sruthi and George 2017). For example, in Brazil about 204 thousand tons of silicon-based ferroalloys were produced in 2012 (Brazilian Metallurgical Industry 2015), which, according to Dal Molin (2005), produces 71.4 thousand tons of SF. Brazil has also produced 11.6 million tons of rice in $2017,20 \%$ of which corresponds to husk. When this husk was burnt, it yielded 464 thousand tons of ash. This has led to a serious environmental problem (Tashima et al. 2012; IBGE 2017).

Wood-cement panels are one of the materials that can be produced so as to add value to the waste residues as mentioned above (Claramunt et al. 2015). These panels provide several advantages when compared with wood products or asbestos cement. These include resistance to both fire and weather, as well as good acoustic insulation, dimensional stability, resistance to the effect of use of biodegradable agents, high resistance to its low weight, and they do not emit toxic residues during its production (Fan et al. 2012; Hamouda et al. 2015; Tichi et al. 2016). Besides, it is not proper to use asbestos due to the already existing ban for its use in several countries around the world as well as in some of the Brazilian states (National Congress of Brazil 1995; EC 2002; Tichi et al. 2016). However, according to a recent report, asbestos is now banned in the whole of Brazil [http://www.ibasecretariat.org/lka-brazil-bans-asbestos.php. Dated: $4^{\text {th }}$ Nov.2019].

According to Fan et al. (2012), the calcium hydroxide $\left[\mathrm{Ca}(\mathrm{OH})_{2}\right]$ remaining in the hydrated cementitious matrix increased the $\mathrm{pH}$ of the wood pulp to approximately 12.5 . This resulted in swelling, dissolution, and degradation of the wood. The authors have opined that increase in $\mathrm{pH}$ can remove a large part of the extractives and dissolve considerable parts of the wood components, especially hemicelluloses, besides causing dimensional changes in the wood-cement composite.

It is relevant to mention here that studies carried out in the University of Guadalahara, Mexico have shown that the presence of sugars affects the curing process of cement. However, it is not so much the effect of $\mathrm{pH}$, but the amount of sugars that affects and hence it is sometimes customary to wash the fibers with hot water to eliminate the sugars. The $\mathrm{pH}$ value normally in wood is slightly acidic (4 to 5), and an alkaline chemical treatment is the only thing that can change the $\mathrm{pH}$ value in wood.

Some authors have reported that the raising of $\mathrm{pH}$ may also help to inhibit the poisoning effect of wood extractives (mostly sugars) on the cement setting process (Vaickelionis and Vaickelioniene 2006; Hamdon 2008).

Some authors have recommended the use of pozzolana, such as active silica and rice husk ash, in order to reduce the alkalinity of the cementitious matrix (Mohr 2005; Lima and Iwakiri 2011). According to these authors the reason for the above is due to the reaction that occurs between the wood-cement and pozzolana. This is understandable based on the pozzolanic reaction, which proceeds as follows: during the hydration reactions of $\mathrm{C}_{2} \mathrm{~S}$ and $\mathrm{C}_{3} \mathrm{~S}, \mathrm{Ca}(\mathrm{OH})_{2}$ forms. The silica present in the pozzolana reacts with $\mathrm{Ca}(\mathrm{OH})_{2}$, forming the hydrated calcium silicates, $\mathrm{CaO}-\mathrm{SiO}_{2}-\mathrm{H}_{2} \mathrm{O}(\mathrm{CSH})$, which have a lower $\mathrm{CaO}-\mathrm{SiO}_{2}$ reaction, forming products of lower basicity than those produced by the hydration of calcium silicates from the cement and therefore are more chemically stable. These reactions, as well as the rate of release of heat and the development of resistance, are slow and occur according to the following Eqs. 1 and 2 (Ardanuy et al. 2015): 


$$
\begin{aligned}
& \text { Pozzolana }+\mathrm{Ca}(\mathrm{OH})_{2}+\mathrm{H}_{2} \mathrm{O} \rightarrow \mathrm{CSH} \\
& 3 \mathrm{Ca}^{++}+2 \mathrm{H}_{2} \mathrm{SiO}_{4}{ }^{2-}+2 \mathrm{OH}^{-}+2 \mathrm{H}_{2} \mathrm{O} \rightarrow \mathrm{Ca}_{3}\left[\mathrm{H}_{2} \mathrm{Si}_{2} \mathrm{O}_{7}\right](\mathrm{OH})_{2} \times 3 \mathrm{H}_{2} \mathrm{O}
\end{aligned}
$$

The Brazilian standard ABNT NBR 15.895 (2010) and the French standard AFNOR NF P18-513 (2010) mention a modified version of the Chapelle method, which is the most used methodology to determine the fixed $\mathrm{Ca}(\mathrm{OH})_{2}$ content in a material with pozzolanic characteristics and is expressed in mg of calcium oxide $(\mathrm{CaO})$ or $\mathrm{Ca}(\mathrm{OH})_{2}$ per $\mathrm{g}$ of pozzolana. In Brazil, the pozzolanicity of the material is allowed when $\mathrm{CaO}$ consumption exceeds $330 \mathrm{mg} \mathrm{CaO} / \mathrm{g}$ pozzolana. By stoichiometry, this value corresponds to $436 \mathrm{mg} \mathrm{Ca}(\mathrm{OH})_{2} / \mathrm{g}$ pozzolana (Macioski et al. 2017).

From the foregoing it has become evident that (i) Brazil has waste materials, such as SF, RHA, and other large amounts of wood waste (e.g., pine wood), (ii) there is a possibility for their use to develop value-added products, such as wood-cement composites, and (iii) the durability of such new material has not been studied thoroughly. In fact, Claramunt et al. (2015) have stated that the use of materials based on composites containing fibers and/or natural particles represents a field of great interest in the research of new materials for civil construction. They further opined that such materials will have good physical and mechanical properties underlining the fact no study on their durability with time has been made.

Accordingly, the objective of the study presented in this paper was to develop wood-cement panels using Portland cement and the pozzolana SF and RHA to study the influence that a high content of pozzolana could have on the properties of wood-cement composite panels. Towards this objective, weathering tests were performed by exposing the material to the weather (natural weathering) or through simulations in the laboratory (accelerated weathering). Natural weathering tests are those in which materials are subjected to or exposed to specific degradation factors that may occur as a function of their natural weathering, such as exposure to the open air (Stark et al. 2004). In the accelerated weathering tests, the material is exposed to a sequence of degradation factors under controlled conditions, such as wetting and drying cycles (Drochytka and Petránek 2007). The durability of the material was determined based on the mechanical characteristics of the prepared composites after natural and accelerated weathering tests.

\section{EXPERIMENTAL}

\section{Materials}

Materials used in study include the residue of species of pine (Pinus spp.), hereafter called as particles of Pinus spp., SF, RHA, Portland cement, and the pozzolanas: SF and RHA and Portland cement.

The Pinus spp. particles were obtained from Almirante Tamandaré, a timber company Paraná, Brazil. The SF of Silmix ${ }^{\mathrm{TM}}$ was obtained from Camargo Corrêa Metais in Curitiba, Paraná, Brazil, who produce and market silica in Brazil. The RHA was obtained from Cia Arroz Urbano in Jaraguá do Sul, Santa Catarina, Brazil, producer and retailer of rice grains in the Brazil. The company generates the rice husk ash by using this husk as fuel during rice processing. The Portland cement (CPV-ARI) of Itambé ${ }^{T M}$ used in this study was donated by the cement manufacturing company, Cia de Cimento Itambé, Curitiba, Paraná, Brazil. The calcium chloride dihydrate $\left(\mathrm{CaCl}_{2} \times 2 \mathrm{H}_{2} \mathrm{O}\right)(\mathrm{pH}=8.50)$ was obtained from IPC do Nordeste Ltda, Camaçari, Bahia, Brazil. The polycarboxylate superplasticizer

De Lima et al. (2020). "Durable wood-cement panels," BioResources 15(2), 3064-3086. 3066 
additive $(\mathrm{pH}=6.75)$ (MC-PowerFlow 1095) was obtained from MC Bauchemie do Brasil, Vargem Grande Paulista, São Paulo, Brazil.

\section{Methods}

Characterization of raw materials used

The total extractives content in the Pinus spp. particles used in this study was determined according to the TAPPI T204 cm-17 (2017) standard and the pH of the wood was determined according to the TAPPI T252 om-16 (2016) standard.

The pozzolanic activity index (PAI) of the pozzolanas was determined using the modified Chapelle method, in accordance with the standards ABNT NBR 15.895 (2010) and AFNOR NF P18-513 (2010). In this method, the constituents were mixed in the ratio of $1: 2$ by mass of the pozzolanic material and $\mathrm{CaO}$. The materials were mixed in an Erlenmeyer flask with $250 \mathrm{~mL}$ of a sucrose solution $(240 \mathrm{~g} / \mathrm{L})$ and were stirred in a thermostatic bath at $90{ }^{\circ} \mathrm{C} \pm 5{ }^{\circ} \mathrm{C}$ for $16 \mathrm{~h}$. Then, the material was filtered before the alkalinity and the remaining (free) $\mathrm{CaO}$ content were determined by titration with hydrochloric acid using phenolphthalein as an indicator.

The result was expressed in $\mathrm{mg}$ of $\mathrm{CaO}$ fixed per $\mathrm{g}$ of pozzolanic material. The content of the $\mathrm{CaO}$ fixed by pozzolana was then determined by the following Eq. 3,

$$
P A I=1.32 \times\left[\frac{28 \times\left(V_{3}-V_{2}\right) \times F c}{2}\right]
$$

where $P A I$ is the content of $\mathrm{Ca}(\mathrm{OH})_{2}$ assimilated by pozzolana $(\mathrm{mg} / \mathrm{g}), V_{3}$ is the volume of $0.1 \mathrm{M} \mathrm{HCl}$ consumed in the test with the sample $(\mathrm{mL}), V_{2}$ is the volume of $0.1 \mathrm{M} \mathrm{HCl}$ consumed with $\mathrm{CaO}(\mathrm{mL}), F c$ is a correction factor of $\mathrm{HCl}$ for $0.1 \mathrm{M}$ concentration after standardization, and 1.32 is the $\mathrm{Ca}(\mathrm{OH})_{2}$ to $\mathrm{CaO}$ molar ratio.

After determining the $\mathrm{Ca}(\mathrm{OH})_{2}$ content fixed by the pozzolanas, the minimum amounts of SF and RHA, which are sufficient and necessary for assimilation of all $\mathrm{Ca}(\mathrm{OH})_{2}$ of the hydrated cement, were determined (these would be the minimum amounts of pozzolanas to enable the assimilation of all available $\mathrm{Ca}(\mathrm{OH})_{2}$ (remaining) after the hydration reactions of the cement). Based on the chemical composition of the Portland cement provided by the manufacturer, the composition of anhydrous cement compounds was determined using the Bogue equations (Neville and Brooks 2013). From the content of the anhydrous compounds, it was possible to proceed with the calculation of the hydrated compounds as well as to determine the remaining $\mathrm{Ca}(\mathrm{OH})_{2}$ content after the final process of cement hydration through the stoichiometric calculations (Neville and Brooks 2013).

\section{Chemical analysis of raw materials}

The chemical composition of the raw materials was determined by X-ray fluorescence (XRF) using an XRF spectrometer (MagiX Pro PW 2540; PANalytical, Westborough, MA, USA).

\section{Preparation of wood-cement panels}

It is well known that substitutions are used depending on the mass of the cement, and accordingly for higher cement content used, higher pozzolana contents were used with a view to maximize the effect of substitutions. Accordingly, the proportion used was 13 parts of cement (or cement plus pozzolanas) to 1 part of wood, based on the dry weight of the materials. The dosage of the materials used was for a specific nominal mass of the panels of $1,500 \mathrm{~kg} / \mathrm{cm}^{3}$. 
It may be noted that amount of water added was that required for the wood to reach the fiber saturation point (FSP). This was done to avoid the wood below the FSP eventually absorbed some of the water intended for cement hydration and pozzolanic reactions. Accordingly, in order to have appropriate water content in the prepared panels, an extra amount of $(0.3 \mathrm{~g})$ of water per gram of wood particle was used as suggested by Fredriksson (2010), who determined the wood fiber saturation point as $30 \%$.

The particles of Pinus spp. were initially pretreated by cold water extraction for 24 h. The adhesive accelerator (polycarboxylate superplasticizer) content of about $4.5 \%$ in relation to the mass of the cement in the composite was used. It may be noted that the superplasticizer additive content in the composites with partial replacements of the cement by the pozzolanas varied according to the content and type of pozzolana used. The composite having a constant consistency of $250 \mathrm{~mm} \pm 5 \mathrm{~mm}$ was adopted as the standard in the present study in view of the fact that the reference composite produced by the authors without substitutions to the Portland cement showed the same value of consistency. The consistency of the fresh mixture is determined by changing the diameter of a quantity of material, which is placed in a cone-shaped mold, after a period of vibration (30 seconds) on a standardized table. The more fluid the fresh mixture, the larger the final diameter of the mixture and consequently the less its consistency. This is the way used to measure the amount of plasticizer additive or superplasticizer, without increasing the amount of water in the mixture and achieving the same plasticity (consistency). It is a common parameter in research with pastes, mortars and even Portland cement-based concretes. This test is standardized in Brazil by the standard NBR 7215 (ABNT 2009).

The consistency of the composite was determined by the use of a flow table. A flow table is an equipment that measures the consistency of a cementitious material in the fresh state by unrestrained slipping of the material, imposed by a standard vibration, determined by small falls from the top of the equipment, called a "table," hence the name "flow table." The material was placed in a standard cone-trunk mold and was densified in a standardized way. After the mold has been removed, the material was tested by 30 falls of table in a period of $30 \mathrm{sec}$. The consistency value was the average diameter of the material after the test was completed. The used Pozzolanas were extremely thin, and it was therefore necessary to add additional water to obtain the same consistency as the reference composite. This greatly affected the water to binder ratio and contributed to a significant reduction in the mechanical characteristics of the material due to the excess pores that remained in the cementitious matrix in the hardened state. In order to limit the amount of water added and to maintain the consistency (workability and to allow the molding of the panels), the same determination was made in the flow table by adding the superplasticizer additive until the consistency of $250 \mathrm{~mm} \pm 5 \mathrm{~mm}$ was obtained for the reference composite without pozzolanas. This resulted in a SP content of $1 \%$ for both panels produced with $30 \%$ SF and those produced with $35 \%$ RHA.

The mixing of the materials was completed by a grating mixer, which gave the material a better homogeneity. The panels of $270 \mathrm{~mm} \times 220 \mathrm{~mm} \times 12.5 \mathrm{~mm}$ were made by cold compression using an EMIC-DL 30000 universal testing machine (Instron Brasil Equipamentos Científicos Ltda., São José dos Pinhais, Paraná, Brazil). For this purpose, a specific pressure of $40 \mathrm{kgf} / \mathrm{cm}^{2}$ was used with four panels superimposed in a sequence and kept under restraint by stapling for a period of $24 \mathrm{~h}$. After this period, referred to as the initial cure, the demolding was completed by removing the fixing clips. The panels were kept in a humid chamber at a temperature of $23{ }^{\circ} \mathrm{C} \pm 2{ }^{\circ} \mathrm{C}$ with a relative humidity $(\mathrm{RH}) \geq$ 
95\%. After the initial curing, the specimens were demolded, covered in plastic bags, and kept in a humid chamber for the final period of curing until the test date.

A total of 21 panels were produced, 7 of which were used as a reference (without the Portland cement substitution) and 7 for each of the 2 additions, viz., SF (30\%) and RHA (35\%). Tables 1 and 2 show the compositions of the prototype panels and the experimental design.

Table 1. Composition of Prototype Panels

\begin{tabular}{|c|c|c|c|c|}
\hline Panel & Cement (\%) & Pozzolana (\%) & $\mathrm{CaCl}_{2} .2 \mathrm{H}_{2} \mathrm{O}(\%)$ & $\mathrm{SP}(\%)$ * \\
\hline REF * & 100 & - & 4.5 & - \\
\hline $\begin{array}{c}\text { SF30 } \\
\text { (Corrected) }\end{array}$ & 70 & 30 & 4.5 & 1.0 \\
\hline RHA35 & 65 & 35 & 4.5 & 1.0 \\
\hline
\end{tabular}

Table 2. Number of Prototype Panels and Determinations

\begin{tabular}{|c|c|c|c|c|c|c|c|c|}
\hline \multirow{3}{*}{ Panel } & \multirow{3}{*}{$\begin{array}{l}\text { Initial } \\
\text { Duration } \\
\text { (28 d) }\end{array}$} & \multicolumn{6}{|c|}{ Treatment } & \multirow{3}{*}{$\begin{array}{c}\text { Number } \\
\text { of } \\
\text { Panels }\end{array}$} \\
\hline & & \multicolumn{4}{|c|}{ Accelerated Weathering (Cycles) } & \multicolumn{2}{|c|}{$\begin{array}{c}\text { Natural } \\
\text { Weathering } \\
\text { (Months) }\end{array}$} & \\
\hline & & $5 \mathrm{C}$ & $10 \mathrm{C}$ & $20 \mathrm{C}$ & $40 C$ & $6 \mathrm{M}$ & $12 \mathrm{M}$ & \\
\hline REF * & 1 & 1 & 1 & 1 & 1 & 1 & 1 & 7 \\
\hline SF30 & 1 & 1 & 1 & 1 & 1 & 1 & 1 & 7 \\
\hline RHA35 & 1 & 1 & 1 & 1 & 1 & 1 & 1 & 7 \\
\hline Total & & & & & & & & 21 \\
\hline
\end{tabular}

These are shown in Fig. 1, wherein Fig. 1a shows the setup for natural weathering (after 6 months and 12 months of exposure to the environment), and Figs. 1b and 1c show the setup for the accelerated weathering after 5 cycles, 10 cycles, 20 cycles, and 40 cycles of wetting and drying, respectively.

It may be noted that for the accelerated weathering of the panels, 48-h cycles were used, which were divided into $23.5 \mathrm{~h}$ of water immersion at $22 \pm 5{ }^{\circ} \mathrm{C}$ followed by $0.5 \mathrm{~h}$ air conditioning at $22 \pm 5{ }^{\circ} \mathrm{C}(\mathrm{RH} 60 \% \pm 5 \%)$. This was then followed by keeping the panels for $23.5 \mathrm{~h}$ in a hot air oven at $60{ }^{\circ} \mathrm{C} \pm 5^{\circ} \mathrm{C}$, which was then finally kept for $0.5 \mathrm{~h}$ in air conditioning at $22{ }^{\circ} \mathrm{C} \pm 5{ }^{\circ} \mathrm{C}(\mathrm{RH} 60 \% \pm 5 \%)$. On the other hand, natural weathering was performed with the panels exposed to the environment, on a bench with a $30 \%$ inclination with the horizontal as shown in Fig. 1a.

The workbench with the panels was oriented to the north. Climatological data for the test site and region are: Latitude: -25.4284; Longitude: - 48.2733 (25 ${ }^{\circ} 25^{\prime} 42$ "South, $49^{\circ} 16^{\prime} 24^{\prime \prime}$ West); Elevation: $925 \mathrm{~m}$; Average daily solar radiation in the horizontal plane: $4.13 \mathrm{kwh} / \mathrm{m}^{2}$.day. Average rainfall in 2018: $123.67 \mathrm{~mm}$, Average temperature in 2018: $21.02{ }^{\circ} \mathrm{C}$; $\mathrm{Cfb}$ (Koppen-Geiger) temperate climate. Source: www.climatempo.com.br/ climatologia/271/curitiba-pr

De Lima et al. (2020). "Durable wood-cement panels," BioResources 15(2), 3064-3086. 3069 


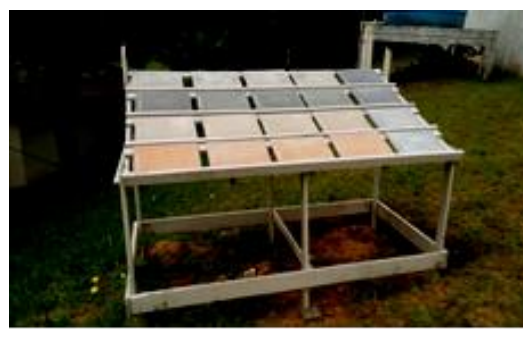

(a)

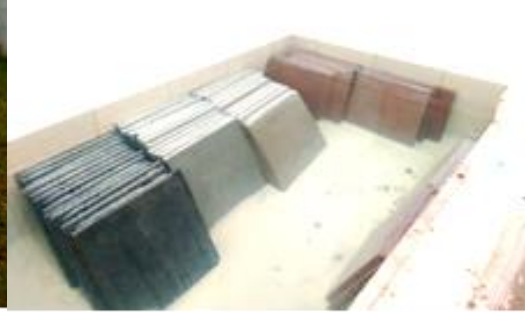

(b)

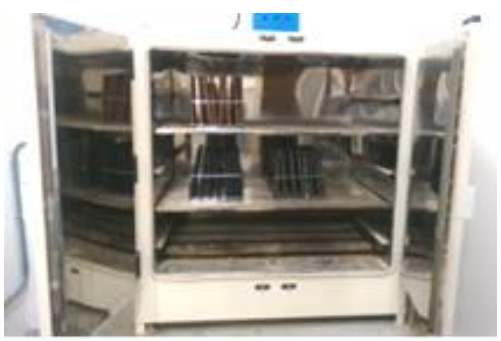

(c)

Fig. 1. Natural and accelerated weathering tests of prototype panels: (a) natural weathering, (b) saturation of panels, and (c) drying of panels.

\section{Characterization of Panels}

The panels were sawn to prepare the specimens for evaluating different properties, which included composition of panels, specific dry mass (SDM), thickness swelling (TS), mechanical properties (compressive strength, internal bond, MOR, MOE, etc.) and morphology of all the panels prepared were determined as per the standards mentioned for each property.

\section{Density of panels}

The density of the prototype panels was determined according to the standards ABNT NBR 9.778 (2009) and ASTM C642 (2013).

\section{Morphology studies and chemical constituents}

Morphology studies of all the prepared panels were performed using a scanning electron microscope (SEM) (Zeiss SEM, EVO MA 15; Carol Zeiss Jena GmbH, Jena, Germany). The effects of the accelerated weathering, natural weathering, and addition of pozzolanas to the composite microstructure were analyzed using an X-ray dispersive energy spectrometer (EDS) (Silicon Drift Detector, Ultim Max; Oxford Instruments, Abingdon, Oxfordshire, UK), which provides an accurate elemental chemical analysis of the microstructure of the composite.

The specimens for morphology studies were prepared by drying at $60{ }^{\circ} \mathrm{C}$ for $48 \mathrm{~h}$ in an oven and then heated for $24 \mathrm{~h}$. After drying, the samples were cut and metalized with gold, due to the low electrical conductivity of the cementitious composites, using a Quorum Q150R ES Plus (Quorum Technologies Ltd., Laughton, East Sussex, UK) instrument.

\section{Thickness swelling}

The thickness swelling (TS) after $24 \mathrm{~h}$ was determined using 4 test pieces with the dimensions $50 \mathrm{~mm} \times 50 \mathrm{~mm} \times 12.5 \mathrm{~mm}$ (length $\times$ width $\times$ height) according to the European standard EN 317 (1993). In brief, the test specimens were packed in an environment with a $\mathrm{RH}$ of $65 \% \pm 5 \%$ and a temperature of $20{ }^{\circ} \mathrm{C} \pm 2{ }^{\circ} \mathrm{C}$ up to a mass balance with a difference of $>0.1 \%$ in $24 \mathrm{~h}$. The thickness of the specimens was then measured with a micrometer with an accuracy of $0.0254 \mathrm{~mm}$ and immersed in water at a constant temperature of $20{ }^{\circ} \mathrm{C} \pm 1{ }^{\circ} \mathrm{C}$ for $24 \mathrm{~h}$. After this period, the excess water was removed and the thickness of the specimens was measured. The TS was then calculated using the following Eq. 4, 


$$
T S=\frac{t_{2}-t_{1}}{t_{1}} \times 100
$$

where TS is the measure of the thickness swelling of the specimens $(\%), t_{1}$ is the measured thickness of the specimens $(\mathrm{mm})$, and $t_{2}$ is the measure of the thickness of the specimens after excess water was removed $(\mathrm{mm})$.

\section{Mechanical testing}

Samples were prepared for different mechanical property determinations according to the standard ASTM D1037 (2012) as follows: For the compressive strength (CS), internal bond strength (IB), static bending for modulus of rupture (MOR) and modulus of elasticity (MOE), 8 test pieces with dimensions $25 \mathrm{~mm} \times 100 \mathrm{~mm} \times 12.5 \mathrm{~mm}, 6$ test pieces with dimensions $50 \mathrm{~mm} \times 50 \mathrm{~mm} \times 12.5 \mathrm{~mm}$, and 4 test pieces with dimensions $50 \mathrm{~mm} \times$ $250 \mathrm{~mm} \times 12.5 \mathrm{~mm}$, respectively.

The mechanical characteristics of the panels were determined after different conditions of exposure as follows: The control samples were cured for $28 \mathrm{~d}$, the natural weathering was carried out for 6 months and 12 months with exposure to the environment, and the accelerated weathering was carried out for 5 cycles, 10 cycles, 20 cycles, and 40 cycles of wetting and drying.

The cycles of experimental conditions used included the time required for saturation $(15 \mathrm{~h})$ and total drying $(21 \mathrm{~h})$ of the composites. Details of the artificial weathering and the natural weathering have been mentioned earlier (see under 'preparation of wood panels' page 6 , last para).

The determined values of the mechanical properties, viz., CS, IB, and static bending using MOR and MOE were compared to the reference values of the Bison Panel production process followed by Nagarjuna Cement Ltd. (NCL 2011) and compared, also, with the limit values established by the BSI EN 310 (BSI, 1993), BSI EN 317 (BSI, 1993), BSI EN 321 (BSI, 2002) and BSI EN 323 (BSI, 1993) standards. The results were statistically analyzed using Statgraphics Centurion 18 software (Statpoint Technologies Inc., Warrenton, VA, USA) through analysis of variance (ANOVA), and the means of the values found were compared through the Tukey test at a confidence level of $95 \%$.

\section{RESULTS AND DISCUSSION}

\section{Particle Size}

The sieved Pinus spp. particles of pine wood exhibited continuous particle size distribution with $99.7 \%$ of the particles ranging in size from $0.075 \mathrm{~mm}$ to $4.8 \mathrm{~mm}$. The total extractive content in the Pinus spp. particles was $2.43 \%$. This value was lower than that of earlier reported values such as 3.58\% (Zanuncio et al. 2015) and 3.50\% (Backlund et al. 2014). Value of the $\mathrm{pH}$ obtained was 5.07, which was close to those of earlier reported values of 5.5 reported by Iwakiri et al. (2012), but higher than the values of 3.9 to 4.6, reported by Poonia and Tripathi (2018). The above differences between the values of the present study and the ones reported earlier may be due to species variation as the species used by the latter researchers are Pinus radiata (Zanuncio et al. 2015) and Pinus contorta (Backlund et al. 2014). 
Chemical analysis of raw materials

The chemical and physical characteristics of the cement supplied by the manufacturer and the pozzolanas measured by fluorescence spectroscopy and X-ray diffraction techniques are shown in Table 3.

Table 3. Chemical and Physical Characteristics of Portland Cement and Pozzolanas

\begin{tabular}{|c|c|c|c|}
\hline Chemical Constituents & Cement & SF & RHA \\
\hline $\mathrm{SiO}_{2}(\%)$ & 18.86 & 95.80 & 70.56 \\
\hline $\mathrm{Al}_{2} \mathrm{O}_{3}(\%)$ & 4.19 & 0.07 & 0.17 \\
\hline $\mathrm{Fe}_{2} \mathrm{O}_{3}(\%)$ & 2.56 & 0.06 & 0.15 \\
\hline $\mathrm{CaO}(\%)$ & 60.51 & 0.23 & 0.20 \\
\hline $\mathrm{MgO}(\%)$ & 4.21 & 0.48 & 0.03 \\
\hline $\mathrm{K}_{2} \mathrm{O}(\%)$ & - & 0.67 & 0.03 \\
\hline $\mathrm{NaO}_{2}(\%)$ & - & 0.18 & - \\
\hline $\mathrm{SO}_{3}(\%)$ & 2.96 & - & 0.40 \\
\hline $\mathrm{Loss} \mathrm{to} \mathrm{fire} \mathrm{( \% )}$ & 3.44 & - & - \\
\hline $\mathrm{H}_{2} \mathrm{O}(\%)$ & - & 0.29 & - \\
\hline $\mathrm{pH}$ & 12.73 & 8.82 & 6.00 \\
\hline $\mathrm{Sp}$ Surface $\left(\mathrm{m}^{2} / \mathrm{kg}\right)$ & 4.29 & 220.00 & 14.78 \\
\hline Density $\left(\mathrm{kg} / \mathrm{m}^{3}\right)$ & 3090 & 2190 & 2020 \\
\hline
\end{tabular}

Based on the chemical composition of anhydrous cement shown in Table 3, the content of $\mathrm{Ca}(\mathrm{OH})_{2}$ in the Portland cement (CPV-ARI) was calculated by stoichiometry and based on the chemical characteristics reported by the manufacturer as $27.4 \%$. This value was slightly higher than the reported reference values that range from $20 \%$ to $25 \%$ (Mehta and Monteiro 2013).

Similarly, the pozzolanic activity index values determined for the SF (PAI $\mathrm{SF}_{\mathrm{SF}}=$ $\left.656.0 \mathrm{mg} \mathrm{Ca}(\mathrm{OH})_{2} / \mathrm{g} \mathrm{SF}\right)$ and for the RHA $\left(\mathrm{PAI}_{\mathrm{RHA}}=588.6 \mathrm{mg} \mathrm{Ca}(\mathrm{OH})_{2} / \mathrm{g} \mathrm{RHA}\right)$ were obtained by the Chapelle method. These values were higher than the recommended minimum value of $330 \mathrm{mg} \mathrm{Ca}(\mathrm{OH})_{2} / \mathrm{g}$ pozzolana (Gobbi 2014; Macioski 2017).

It was observed that the minimum as well as sufficient content of pozzolanas determined to assimilate the $27.4 \% \mathrm{Ca}(\mathrm{OH})_{2}$ produced in the hydration of the cement were 29.4\% SF and 31.8\% RHA. Therefore, theoretically, the substitution of these quantities of pozzolanas should assimilate all the $\mathrm{Ca}(\mathrm{OH})_{2}$ in the Portland cement. However, these values were rounded off to $30 \% \mathrm{SF}$ and $32 \%$ RHA to facilitate the calculations.

Before starting the production process of the composites, an analysis of the superplasticizer (SP) additive consumption was performed to maintain the composite consistency at $250 \mathrm{~mm} \pm 5 \mathrm{~mm}$ determined using a flow table.

\section{Density of the panels}

The density values of prototype panels in the dry state were found to be $1570 \mathrm{~kg} / \mathrm{m}^{3}$, $1320 \mathrm{~kg} / \mathrm{m}^{3}$ and $1400 \mathrm{~kg} / \mathrm{m}^{3}$ for the reference (REF) panels, SF30 panels and RHA35 panels, respectively. These values were higher than the value $1000 \mathrm{~kg} / \mathrm{m}^{3}$ as recommended by the British standard BSI EN 323 (1993). The density of the reference panels was $4.67 \%$ higher than the nominal density, and the panels produced with the Portland cement substitutions resulted in mass reductions of $15.9 \%$ (SF30) and $10.4 \%$ (RHA35) relative to the values of the reference panels. This could be anticipated because the specific mass values of pozzolanas were lower than that of the cement. This shows that both the cement

De Lima et al. (2020). "Durable wood-cement panels," BioResources 15(2), 3064-3086. 3072 
substitution content and the type of weathering adopted had no effect on this panel property.

\section{Thickness swelling (TS)}

Table 4 lists the TS values of all the panels prepared in this study, which were obtained by Turkey's method within the same test and among different treatments used as well as all the prepared panels in this study (applying the factorial ANOVA to see any differences among various treatments). Further, it may be noted that Tukey's method implies that a statistical analysis of ANOVA has already been done and serves to establish differences between the averages of the different materials studied. Equal letters indicate that there is no statistical difference and if they are different letters, then they are statistically different. It may also be noted that there is no need for other statistical treatment than that used. This is the standard treatment used by researchers in the field of cementwood panels.

It can be seen that there were no significant statistical differences for the average values of swelling thickness of the panels among treatments, both for those exposed to natural weathering and for those that went through the wetting and drying cycles of the accelerated weathering. In addition, these observed results for all panels were lower than the limit value, which was $1.8 \%$, indicated by the Bison Panel process used by the Nagarjuna Cement Ltd. (NCL 2011) and also lower than the maximum value referred to in BSI 317 (BSI, 1993), which is $1.5 \%$. It may be noted that the material adopted as a benchmark in the present study was that produced by Bison (NCL), as it is a commercialized material of recognized quality and hence no other data is given for comparison.

Table 4. Variation of Swelling Thickness

\begin{tabular}{|c|c|c|c|c|c|c|c|c|}
\hline \multirow{2}{*}{\multicolumn{2}{|c|}{ Panel }} & \multirow{2}{*}{28 Days } & \multicolumn{4}{|c|}{ Accelerated Weathering (AW) } & \multicolumn{2}{|c|}{$\begin{array}{c}\text { Natural } \\
\text { Weathering (NW) }\end{array}$} \\
\hline & & & AW5C & AW10C & AW20C & AW40C & NW6M & NW12M \\
\hline \multirow{3}{*}{ REF } & ST (\%) & $0.20^{\mathrm{AB}}$ & $0.20^{\mathrm{AB}}$ & $0.19^{\mathrm{AB}}$ & $0.15^{\mathrm{B}}$ & $0.18^{\mathrm{AB}}$ & $0.19^{A B}$ & $0.18^{\mathrm{AB}}$ \\
\hline & CV (\%) & 22.61 & 30.47 & 15.18 & 6.30 & 17.18 & 44.49 & 11.14 \\
\hline & $\begin{array}{l}\text { Error } \\
(\%)\end{array}$ & 0.022 & 0.030 & 0.015 & 0.005 & 0.016 & 0.042 & 0.010 \\
\hline \multirow{3}{*}{ SF30 } & ST $(\%)$ & $0.22^{\mathrm{AB}}$ & $0.20^{\mathrm{AB}}$ & $0.20^{\mathrm{AB}}$ & $0.21^{\mathrm{AB}}$ & $0.20^{\mathrm{AB}}$ & $0.20^{A B}$ & $0.21^{\mathrm{AB}}$ \\
\hline & CV (\%) & 25.79 & 19.03 & 28.01 & 48.97 & 24.49 & 24.27 & 6.74 \\
\hline & $\begin{array}{c}\text { Error } \\
(\%)\end{array}$ & 0.028 & 0.019 & 0.028 & 0.051 & 0.024 & 0.024 & 0.007 \\
\hline \multirow{3}{*}{ RHA35 } & ST $(\%)$ & $0.23^{\mathrm{A}}$ & $0.21^{A B}$ & $0.20^{\mathrm{AB}}$ & $0.23^{\mathrm{A}}$ & $0.21^{A B}$ & $0.19^{A B}$ & $0.22^{A B}$ \\
\hline & CV (\%) & 20.05 & 17.67 & 16.50 & 21.23 & 19.92 & 21.30 & 16.11 \\
\hline & $\begin{array}{c}\text { Error } \\
(\%)\end{array}$ & 0.023 & 0.018 & 0.017 & 0.024 & 0.021 & 0.020 & 0.018 \\
\hline \multicolumn{9}{|c|}{$\begin{array}{l}\text { Different letters indicate significant statistical differences at a confidence level of } 95 \% \text {; A and } \\
\text { AB are equal indicating that there is no statistical difference, due to the presence of 'a' in the } \\
\text { two determinations; Averages obtained through } 4 \text { replicates; C: Cycles; SF: Silica fume; RHA: } \\
\text { Rice husk ash; ST: Swelling thickness; CV: Coefficient of variation; Error: Standard error. }\end{array}$} \\
\hline
\end{tabular}

De Lima et al. (2020). "Durable wood-cement panels," BioResources 15(2), 3064-3086. 3073 
The values shown in Table 4 were the averages obtained from 4 replicates with only one determination $\left(20^{\circ} \mathrm{C}\right)$ showed the differences between REF and RHA35 samples, indicating statistical differences between the means at a $95 \%$ confidence level.

\section{Mechanical Properties}

Tables 5 through 8 show the mean values of various mechanical characteristics (i.e., $\mathrm{CS}, \mathrm{IB}, \mathrm{MOR}$, and MOE) of the prepared panels obtained from different numbers of repetitions as indicated under respective tests.

Compressive strength

Table 5 shows the mean values of the CS of the prepared panels obtained from 8 repetitions of the test. In the table, different letters indicate statistical differences between means at a $95 \%$ confidence level.

Table 5. Variation of the Compressive Strength of the Panels

\begin{tabular}{|c|c|c|c|c|c|c|c|c|}
\hline \multirow{2}{*}{\multicolumn{2}{|c|}{ Panel }} & \multirow{3}{*}{28 Days } & \multicolumn{4}{|c|}{ Accelerated Weathering (AW) } & \multicolumn{2}{|c|}{$\begin{array}{l}\text { Natural Weathering } \\
(\mathrm{NW})\end{array}$} \\
\hline & & & \multirow{2}{*}{$\begin{array}{c}\text { AW5C } \\
27.27^{\mathrm{BCD}}\end{array}$} & \multirow{2}{*}{$\begin{array}{l}\text { AW10C } \\
21.22^{\mathrm{FGH}}\end{array}$} & \multirow{2}{*}{$\begin{array}{c}\text { AW20C } \\
15.5^{\mathrm{IJ}}\end{array}$} & \multirow{2}{*}{$\begin{array}{c}\text { AW40C } \\
11.34^{\mathrm{J}}\end{array}$} & \multirow{2}{*}{$\begin{array}{l}\text { NW6M } \\
30.03^{\mathrm{B}}\end{array}$} & \multirow{2}{*}{$\begin{array}{l}\text { NW12M } \\
22.56 \mathrm{EFG}\end{array}$} \\
\hline \multirow{3}{*}{ REF } & $\begin{array}{c}\mathrm{CS} \\
(\mathrm{MPa})\end{array}$ & & & & & & & \\
\hline & $\begin{array}{l}\text { CV } \\
(\%)\end{array}$ & 1.57 & 9.19 & 15.73 & 12.33 & 14.55 & 28.01 & 10.12 \\
\hline & $\begin{array}{l}\text { Error } \\
(\mathrm{MPa})\end{array}$ & 0.27 & 0.95 & 1.18 & 0.71 & 0.67 & 2.97 & 0.81 \\
\hline \multirow{3}{*}{ SF30 } & $\begin{array}{c}\mathrm{CS} \\
(\mathrm{MPa})\end{array}$ & $26.77^{\mathrm{BCD}}$ & $28.63^{\mathrm{BC}}$ & $21.51 \mathrm{FGH}$ & $19.83^{\mathrm{GH}}$ & $14.77^{\mathrm{J}}$ & $25.41 \mathrm{CDE}$ & $24.32^{\mathrm{DEF}}$ \\
\hline & $\begin{array}{l}\text { CV } \\
(\%)\end{array}$ & 13.22 & 16.87 & 12.53 & 13.85 & 17.55 & 9.70 & 12.70 \\
\hline & $\begin{array}{l}\text { Error } \\
(\mathrm{MPa})\end{array}$ & 1.25 & 1.71 & 0.95 & 0.97 & 0.92 & 0.87 & 1.09 \\
\hline \multirow{3}{*}{ RHA35 } & $\begin{array}{c}\mathrm{CS} \\
(\mathrm{MPa})\end{array}$ & $29.57^{B}$ & $35.15^{\mathrm{A}}$ & $26.00^{\mathrm{BCDE}}$ & $21.36 \mathrm{FGH}$ & $15.31^{\mathrm{IJ}}$ & $28.71^{\mathrm{BC}}$ & $18.51^{\mathrm{HI}}$ \\
\hline & $\begin{array}{l}\text { CV } \\
(\%)\end{array}$ & 14.81 & 13.72 & 16.94 & 22.63 & 27.42 & 12.44 & 13.49 \\
\hline & $\begin{array}{l}\text { Error } \\
(\mathrm{MPa})\end{array}$ & 1.55 & 1.82 & 1.66 & 1.78 & 1.48 & 1.35 & 0.94 \\
\hline \multicolumn{9}{|c|}{$\begin{array}{l}\text { Different letters indicate significant statistical differences at a confidence level of 95\%; } \\
\text { Averages obtained through } 8 \text { replicates; CS: Compressive Strength; C: Cycles; SF: Silica } \\
\text { fume; RHA: Rice husk ash; CV: Coefficient of variation; Error: Standard error } \\
\text { :A ; B: ; C: ; D: ; E: ; F: ; G: ; H: ; I: ; J; (Different letters indicate significant statistical differences } \\
\text { at a confidence level of } 95 \% \text {.) }\end{array}$} \\
\hline
\end{tabular}

From Table 5 it can be seen that the obtained CS values show significant differences for the three types of panels as a function of accelerated and natural weathering. The CS values of the panels produced with pozzolanas increased in the first $5 \mathrm{AW}$ cycles and then successively decreased significantly for the three panels produced. The REF panels showed CS losses of $21.5 \%$ at 5 accelerated weathering cycles and $67.4 \%$ losses at 40 cycles. This could be due to the acceleration of the pozzolanic reactions as a function of the increasing temperature for the AW cycles, while the subsequent degradation of the transition zone between the particles of Pinus spp. and the cementitious matrix could be for the higher AW cycles. On the other hand, the naturally aged REF panels after 12 months of natural 
weathering showed $35.0 \%$ loss of SC, while the panels produced with $30 \%$ of SF and $35 \%$ of RHA showed a reduction in the CS values after 28 days of curing by $22.9 \%$ and $14.9 \%$, respectively, in relation to the REF panels. But, these values cannot be compared with those reported for the Bison Panel production process (NCL 2011) as this process does not show reference values for this property.

On the other hand, after 40 cycles of AW, the SF30 and RHA35 panels showed $30.2 \%$ and $35.0 \%$, respectively, higher CS values than those of REF under the same conditions. After 12 months of natural weathering, SF30 panels showed 7.8\% higher CS values than those of REF panels, while RHA35 panels showed 18.0\% lower CS values than REF panels. Observing these values, and considering the highly deleterious effect of accelerated weathering assays, it can be concluded that the use of SF and RHA pozzolanas improved the durability of the prototype panels produced.

Perpendicular tensile strength (Internal bond)

Table 6 lists the obtained values of the resistance to stress in the perpendicular direction (i.e., internal bond). The values obtained in the present study for all panels were above the limit of $0.40 \mathrm{MPa}$, as indicated by the Bison Panel production process (NCL 2011) and higher, also, compared to the minimum value indicated in the BSI EN 321 standard (BSI, 2002), which is $0.41 \mathrm{MPa}$.

Table 6. Variation of the Internal Bond of the Panels

\begin{tabular}{|c|c|c|c|c|c|c|c|c|}
\hline \multirow{2}{*}{\multicolumn{2}{|c|}{ Panel }} & \multirow{3}{*}{$\begin{array}{l}28 \text { Days } \\
1.09^{B C D E}\end{array}$} & \multicolumn{4}{|c|}{ Accelerated Weathering (AW) } & \multicolumn{2}{|c|}{$\begin{array}{c}\text { Natural } \\
\text { Weathering (NW) }\end{array}$} \\
\hline & & & \multirow{2}{*}{$\begin{array}{c}\text { AW5C } \\
1.03^{\mathrm{DEFG}}\end{array}$} & \multirow{2}{*}{$\frac{A W 10 \mathrm{C}}{0.90^{\mathrm{GHI}}}$} & \multirow{2}{*}{$\frac{\text { AW20C }}{0.87^{\mathrm{HI}}}$} & \multirow{2}{*}{$\frac{\text { AW40C }}{0.54^{\mathrm{J}}}$} & \multirow{2}{*}{$\frac{\mathrm{NW6M}}{1.22^{\mathrm{ABC}}}$} & \multirow{2}{*}{$\frac{\mathrm{NW} 12 \mathrm{M}}{0.93^{\mathrm{FGHI}}}$} \\
\hline \multirow{3}{*}{ REF } & $\begin{array}{c}\mathrm{IB} \\
(\mathrm{MPa})\end{array}$ & & & & & & & \\
\hline & $\begin{array}{l}\text { CV } \\
(\%)\end{array}$ & 12.91 & 15.28 & 12.16 & 17.98 & 14.40 & 8.83 & 16.77 \\
\hline & $\begin{array}{l}\text { Error } \\
(\mathrm{MPa})\end{array}$ & 0.06 & 0.05 & 0.04 & 0.06 & 0.03 & 0.05 & 0.06 \\
\hline \multirow{3}{*}{ SF30 } & $\begin{array}{c}\text { IB } \\
(\mathrm{MPa})\end{array}$ & $1.01^{\mathrm{DEFGH}}$ & $1.00^{\mathrm{DEFGH}}$ & $0.89 \mathrm{GHI}$ & $0.80^{1}$ & $0.57^{\mathrm{J}}$ & $1.24^{\mathrm{AB}}$ & 1.17 $\mathrm{ABCD}$ \\
\hline & $\begin{array}{l}\mathrm{CV} \\
(\%)\end{array}$ & 14.78 & 8.50 & 7.43 & 2.23 & 10.87 & 20.33 & 12.11 \\
\hline & $\begin{array}{l}\text { Error } \\
(\mathrm{MPa})\end{array}$ & 0.06 & 0.03 & 0.03 & 0.01 & 0.03 & 0.11 & 0.07 \\
\hline \multirow{3}{*}{ RHA35 } & $\begin{array}{c}\mathrm{IB} \\
(\mathrm{MPa})\end{array}$ & 0.97 EFGH & $1.07^{\mathrm{CDEF}}$ & $0.98^{\mathrm{EFGH}}$ & $0.91^{\mathrm{GHI}}$ & $0.63^{J}$ & $1.31^{\mathrm{A}}$ & $1.10^{\mathrm{BCDE}}$ \\
\hline & $\begin{array}{l}\text { CV } \\
(\%)\end{array}$ & 3.35 & 5.96 & 18.77 & 5.75 & 15.76 & 10.10 & 21.31 \\
\hline & $\begin{array}{l}\text { Error } \\
(\mathrm{MPa})\end{array}$ & 0.01 & 0.02 & 0.08 & 0.02 & 0.04 & 0.05 & 0.10 \\
\hline \multicolumn{9}{|c|}{$\begin{array}{l}\text { Different letters indicate significant statistical differences at a confidence level of 95\%; } \\
\text { Averages obtained through } 6 \text { replicates; IB: Internal bond; C: Cycles; SF: Silica fume; RHA: } \\
\text { Rice husk ash; CV: Coefficient of variation; Error: Standard error } \\
\text { :A ; B: ; C: ; D: ; E: ; F: ; G: ; H: ; I: ; J; (Different letters indicate significant statistical differences } \\
\text { at a confidence level of } 95 \% \text {.). }\end{array}$} \\
\hline
\end{tabular}

De Lima et al. (2020). "Durable wood-cement panels," BioResources 15(2), 3064-3086. 3075 
The values of internal bond strength decreased with the weathering of the material after the AW cycles. In contrast, there was a significant increase in the values of internal bond strength in the NW samples for the three types of panels produced between $28 \mathrm{~d}$ of curing and 6 months of NW. The panels produced with SF increased in their IB values up to 12 months of NW. This can be attributed to the continuity of pozzolanic reactions even after weathering more than 6 months.

\section{Static bending (MOR)}

Table 7 lists the obtained values for the MOR of the prepared panels in this study. None of the panels showed values similar to that of the reference value (the minimum strength being 9.0 MPa) as indicated by the Bison Panel production process (NCL 2011) and BSI EN 310 (BSI, 1993) standard. Increase in the fragility of the panels including the reference panels due to the high binder content used could be the reason for this. In addition, a decreasing trend in the values of static bending (MOR) with increasing weathering time was observed for the three types of panels produced in the AW cycles. On the other hand, obtained MOR values of the NW panels produced with pozzolanas decreased when compared with those of the reference panels. This could have been due to the lower degradation observed by the panels exposed to the environment and by the continuity of the pozzolanic reactions over time.

Table 7. Static Bending (MOR)

\begin{tabular}{|c|c|c|c|c|c|c|c|c|}
\hline \multirow{2}{*}{\multicolumn{2}{|c|}{ Panel }} & \multirow{3}{*}{$\begin{array}{c}28 \text { Days } \\
5.69^{A}\end{array}$} & \multicolumn{4}{|c|}{ Accelerated Weathering (AW) } & \multicolumn{2}{|c|}{$\begin{array}{c}\text { Natural } \\
\text { Weathering (NW) }\end{array}$} \\
\hline & & & \multirow{2}{*}{$\frac{A W 5 C}{4.35^{B}}$} & \multirow{2}{*}{$\begin{array}{l}\text { AW10C } \\
3.98^{\mathrm{BCDE}}\end{array}$} & \multirow{2}{*}{$\frac{\text { AW20C }}{2.97^{\mathrm{HI}}}$} & \multirow{2}{*}{$\frac{\text { AW40C }}{2.10^{\mathrm{J}}}$} & \multirow{2}{*}{$\frac{\mathrm{NW6M}}{4.25^{\mathrm{CB}}}$} & \multirow{2}{*}{$\begin{array}{c}\mathrm{NW} 12 \mathrm{M} \\
3.25^{\mathrm{FGH}}\end{array}$} \\
\hline \multirow{3}{*}{ REF } & $\begin{array}{c}\text { MOR } \\
\text { (MPa) }\end{array}$ & & & & & & & \\
\hline & $\begin{array}{l}\text { CV } \\
(\%)\end{array}$ & 6.48 & 10.86 & 12.00 & 3.60 & 9.72 & 10.53 & 6.64 \\
\hline & $\begin{array}{l}\text { Error } \\
(\mathrm{MPa})\end{array}$ & 0.18 & 0.24 & 0.24 & 0.06 & 0.10 & 0.22 & 0.11 \\
\hline \multirow{3}{*}{ SF30 } & $\begin{array}{l}\text { MOR } \\
(\mathrm{MPa})\end{array}$ & $4.25^{\mathrm{BC}}$ & $4.00^{\mathrm{BCDE}}$ & 3.77CDEF & $3.68^{\mathrm{DEFG}}$ & $2.52^{\mathrm{IJ}}$ & 4.14 $\mathrm{BCD}$ & $3.91^{\mathrm{BCDE}}$ \\
\hline & $\begin{array}{l}\text { CV } \\
(\%)\end{array}$ & 14.48 & 3.23 & 7.55 & 9.64 & 7.87 & 8.38 & 8.43 \\
\hline & $\begin{array}{l}\text { Error } \\
(\mathrm{MPa})\end{array}$ & 0.31 & 0.06 & 0.14 & 0.18 & 0.10 & 0.17 & 0.16 \\
\hline \multirow{3}{*}{ RHA35 } & $\begin{array}{l}\text { MOR } \\
(\mathrm{MPa})\end{array}$ & $5.26^{A}$ & $4.08^{\mathrm{BCD}}$ & $3.52^{\mathrm{EFGH}}$ & $3.16^{\mathrm{GH}}$ & $2.08^{J}$ & 4.19BCD & $3,95^{\mathrm{BCDE}}$ \\
\hline & $\begin{array}{l}\text { CV } \\
(\%)\end{array}$ & 9.18 & 7.43 & 13.98 & 5.00 & 17.54 & 13.26 & 8.12 \\
\hline & $\begin{array}{l}\text { Error } \\
(\mathrm{MPa})\end{array}$ & 0.24 & 0.15 & 0.25 & 0.08 & 0.18 & 0.28 & 0.16 \\
\hline \multicolumn{9}{|c|}{$\begin{array}{l}\text { Different letters indicate significant statistical differences at a confidence level of 95\%; } \\
\text { Averages obtained through } 4 \text { replicates; MOR: Modulus of Rupture in Static Bending; C: } \\
\text { Cycles; SF: Silica fume; RHA: Rice husk ash; CV: Coefficient of variation; Error: Standard } \\
\text { error: A ; B: ; C: ; D: ; E: ; F: ; G: ; H: ; I: ; J; (Different letters indicate significant statistical } \\
\text { differences at a confidence level of 95\%). }\end{array}$} \\
\hline
\end{tabular}

De Lima et al. (2020). "Durable wood-cement panels," BioResources 15(2), 3064-3086. 3076 


\section{Modulus of elasticity (MOE)}

Table 8 lists the MOE values of the panels studied in this work. The table shows that apart from the SF30 panels after 40 cycles of AW and the RHA35 panels after 12 months of NW, all the other panels showed MOE values that were higher than the threshold value of 3.0 GPa, as indicated by the Bison Panel production process (NCL 2011). On the other hand, it appears that REF panels after 40 cycles of AW, SF30 panels after 20 and 40 cycles of AW and 12 months of NW and RHA 35 panels after 10, 20 and 40 cycles of AW 312 months of NW, did not reach the minimum value imposed by the BSI EN 310 (BSI, 1993), which is $4.5 \mathrm{GPa}$. REF panels and panels produced with SF30 and RHA 35 pozzolanas showed decreasing MOE values for each AW cycle. The same decreasing values of MOE were observed in the samples NW6M and NW12M.

Further, the reduction of the observed MOE values for the REF, SF30, and RHA35 panels at both 6 months and 12 months of natural weathering was similar for the three materials in comparison with that of the NW panels. These observed decreases in the MOE values were quite considerable although they did not show statistically significant differences between them.

Table 8. Variation of the Modulus of Elasticity to Static Bending

\begin{tabular}{|c|c|c|c|c|c|c|c|c|}
\hline \multirow{2}{*}{\multicolumn{2}{|c|}{ Panel }} & \multirow{3}{*}{$\begin{array}{c}28 \text { Days } \\
11.19^{A B}\end{array}$} & \multicolumn{4}{|c|}{ Accelerated Weathering (AW) } & \multicolumn{2}{|c|}{$\begin{array}{c}\text { Natural } \\
\text { Weathering (NW) }\end{array}$} \\
\hline & & & \multirow{2}{*}{$\frac{A W 5 C}{12.20^{A}}$} & \multirow{2}{*}{$\frac{A W 10 C}{10.37^{B C}}$} & \multirow{2}{*}{$\frac{\text { AW20C }}{5.59 \mathrm{EF}}$} & \multirow{2}{*}{$\frac{\mathrm{AW} 40 \mathrm{C}}{3.75^{\mathrm{EFG}}}$} & \multirow{2}{*}{$\begin{array}{l}\text { NW6M } \\
5.07^{\mathrm{EFG}}\end{array}$} & \multirow{2}{*}{$\frac{\mathrm{NW} 12 \mathrm{M}}{4.71 \mathrm{EFGH}}$} \\
\hline \multirow{3}{*}{ REF } & $\begin{array}{l}\text { MOE } \\
\text { (GPa) }\end{array}$ & & & & & & & \\
\hline & $\begin{array}{l}\text { CV } \\
(\%)\end{array}$ & 11.15 & 22.91 & 3.84 & 39.04 & 9.42 & 24.61 & 15.77 \\
\hline & $\begin{array}{l}\text { Error } \\
\text { (GPa) }\end{array}$ & 0.62 & 1.40 & 0.20 & 1.26 & 0.20 & 0.62 & 0.37 \\
\hline \multirow{3}{*}{ SF30 } & $\begin{array}{l}\mathrm{MOE} \\
(\mathrm{GPa})\end{array}$ & $9.47 \mathrm{CD}$ & $5.96^{\mathrm{E}}$ & $5.65^{\mathrm{EF}}$ & 4.29FGHI & $2.77^{\mathrm{IJ}}$ & $5.23^{\mathrm{EFG}}$ & $3.41^{\mathrm{HIJ}}$ \\
\hline & $\begin{array}{l}\mathrm{CV} \\
(\%)\end{array}$ & 19.92 & 11.60 & 9.08 & 16.01 & 19.43 & 17.19 & 8.68 \\
\hline & $\begin{array}{l}\text { Error } \\
(\mathrm{GPa})\end{array}$ & 0.94 & 0.35 & 0.26 & 0.34 & 0.27 & 0.52 & 0.18 \\
\hline \multirow{3}{*}{ RHA35 } & $\begin{array}{l}\text { MOE } \\
\text { (GPa) }\end{array}$ & $9.89 \mathrm{BC}$ & $8.06^{\mathrm{D}}$ & $4.42^{\mathrm{FGH}}$ & $3.91^{\mathrm{GHI}}$ & $3.31^{\mathrm{HIJ}}$ & $5.37 \mathrm{EFG}$ & $2.32^{J}$ \\
\hline & $\begin{array}{l}\text { CV } \\
(\%)\end{array}$ & 5.66 & 12.16 & 8.73 & 16.71 & 16.68 & 12.02 & 14.28 \\
\hline & $\begin{array}{l}\text { Error } \\
\text { (GPa) }\end{array}$ & 0.28 & 0.49 & 0.19 & 0.33 & 0.28 & 0.32 & 0.17 \\
\hline
\end{tabular}

Different letters indicate significant statistical differences at a confidence level of $95 \%$; Averages obtained through 4 replicates; MOE: Modulus of elasticity; C: Cycles; SF: Silica fume; RHA: Rice husk ash; CV: Coefficient of variation; Error: Standard error :A ; B: ; C: ; D: ; E: ; F: ; G: ; H: ; I: ; J; (Different letters indicate significant statistical differences at a confidence level of $95 \%$.). 
All the values listed in the above tables (Tables 5-8) are comparable with those presented in the CERTIS Standards as shown below:

Density - BSI EN 323 (1993): $\max 1.0 \mathrm{~g} / \mathrm{cm} 3$

Thickness swelling - BSI EN 317 (1993): $\max 1.5 \%$

Internal Bond - BSI EN 321 (2002): $\min 0.41 \mathrm{MPa}$

Bending Strength (MOR) - BSI EN 310 (1993): min $9 \mathrm{MPa}$

Modulus of Elasticity (MOE) - BSI EN 310 (1993): $\min 4.5 \mathrm{GPa}$

Limit values can also be used according to the specification of CETRIS Basic panels:

Density: $\max 1.35 \mathrm{~g} / \mathrm{cm} 3$

Swelling Thickness: Max $0.31 \%$

Internal Bond: min $0.3 \mathrm{MPa}$

Bending Strength (MOR): $\min 11.5 \mathrm{MPa}$

Modulus of Elasticity (MOE): $\min 6.8 \mathrm{GPa}$.

\section{Morphology studies and chemical constituents}

Figure 2 shows the scanning electron micrographs of the panels. Figure 2 a shows morphology of the REF panels, Fig. 2b shows the morphology of the SF30 panels, and Fig. $2 \mathrm{c}$ shows the morphology of the RHA35 panels taken at two different magnifications (500x and 700x). The numbers in the figures indicate the locations at which measurements were made by EDAX for the chemical composition of the material present. As can be seen in the figures, one can identify whether or not there was precipitation of $\mathrm{Ca}$ crystals in the wood particles and whether or not there was detachment between the wood particle and the cement matrix in the transition zone.

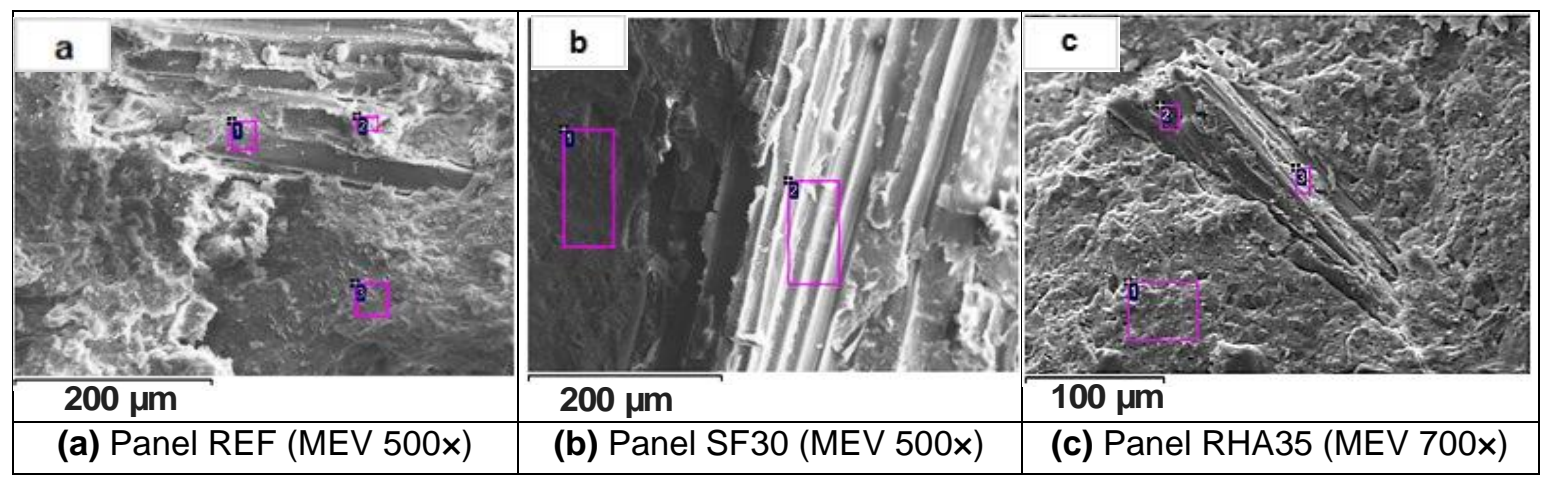

Fig. 2. Scanning electron micrographs and chemical composition of the Pinus spp. particles as determined by EDS after 28 d of curing: (a) Panel REF, (b) Panel SF30, and (c) Panel RHA35. The boxes and numbers shown in the figures refer to the EDS reading points.

Table 9 shows the chemical composition of the Pinus spp. particles, as determined by EDS after curing for $28 \mathrm{~d}$. As shown in Fig. 2, there was no detachment of the particles from the cementitious matrices, and this was attributed to the type of curing used (e.g., immersion in water), which kept the material free from retraction via drying. Small amounts of material precipitation from the cement hydration and cement-pozzolana combination occurred in the cell walls of the Pinus spp. particles and was evidenced by the low amounts of $\mathrm{Ca}, \mathrm{Si}, \mathrm{Al}$, and $\mathrm{Mg}$ present in the samples. 
Table 9. Chemical Composition of the Pinus spp. Particles after Curing for $28 \mathrm{~d}$

\begin{tabular}{|c|c|c|c|c|c|}
\hline \multicolumn{2}{|c|}{ Panel REF } & \multicolumn{2}{c|}{ Panel SF30 } & \multicolumn{2}{c|}{ Panel RHA35 } \\
\hline \multicolumn{2}{|c|}{ Chemical Element (\%) } & \multicolumn{2}{c|}{ Chemical Element (\%) } & \multicolumn{2}{c|}{ Chemical Element (\%) } \\
\hline $\mathrm{C}$ & 39.01 & $\mathrm{C}$ & 50.15 & $\mathrm{C}$ & 41.05 \\
\hline $\mathrm{O}$ & 48.32 & $\mathrm{O}$ & 47.39 & $\mathrm{O}$ & 52.29 \\
\hline $\mathrm{Mg}$ & - & $\mathrm{Mg}$ & - & $\mathrm{Mg}$ & - \\
\hline $\mathrm{Al}$ & 0.25 & $\mathrm{Al}$ & 0.11 & $\mathrm{Al}$ & 0.11 \\
\hline $\mathrm{Si}$ & 0.68 & $\mathrm{Si}$ & 0.38 & $\mathrm{Si}$ & 0.28 \\
\hline $\mathrm{S}$ & - & $\mathrm{S}$ & - & $\mathrm{S}$ & - \\
\hline $\mathrm{Cl}$ & - & $\mathrm{Cl}$ & 0.13 & $\mathrm{Cl}$ & - \\
\hline $\mathrm{K}$ & - & $\mathrm{K}$ & - & $\mathrm{K}$ & 0.20 \\
\hline $\mathrm{Ca}$ & 7.33 & $\mathrm{Ca}$ & 1.84 & $\mathrm{Ca}$ & 6.07 \\
\hline $\mathrm{Fe}$ & 0.29 & $\mathrm{Fe}$ & - & $\mathrm{Fe}$ & - \\
\hline Other & 4.12 & Other & - & Other & - \\
\hline Total & 100.00 & Total & 100.00 & Total & 100.00 \\
\hline
\end{tabular}

Figure 3 shows the scanning electron micrographs of the panels after 12 months of natural weathering. Table 10 lists the chemical composition of the Pinus spp. particles. Figure $3 \mathrm{a}$ shows that there were no voids in the transition zone between the particles of Pinus spp. and the cementitious matrix in the reference panel. This demonstrates the effect of the natural expansion and retraction cycles experienced by the material when it was exposed to the external environment. However, the same phenomenon was not observed in the SF30 and RHA35 panels, suggesting that pozzolanas could have interfered chemically and/or mechanically (e.g., through pore refinement) in this region.

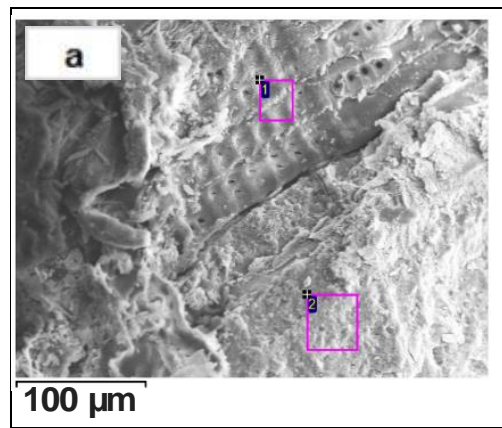

(a) Panel REF (MEV 700x)

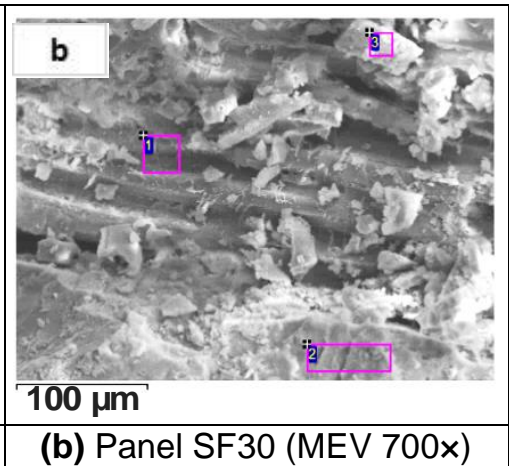

(b) Panel SF30 (MEV 700x)

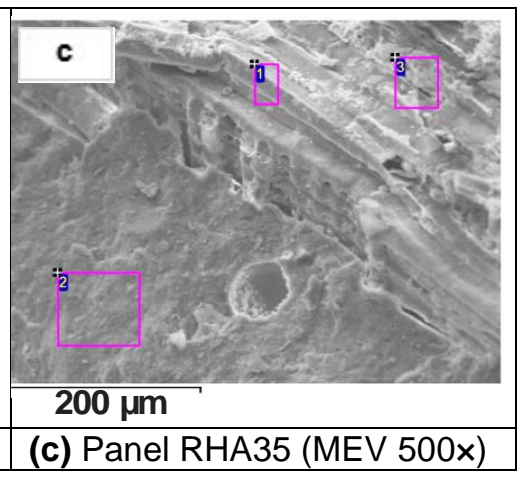

Fig. 3. Scanning electron micrographs and chemical composition of the Pinus spp. particles as determined by EDS after 12 months of natural weathering: (a) Panel REF, (b) Panel SF30, and (c) Panel RHA35. The boxes and numbers shown in the figures refer to the EDS reading points.

Figure 4 shows the scanning electron micrographs of the panels after 40 cycles of accelerated weathering. Table 11 shows the chemical composition of the Pinus spp. particles. As shown in Fig. 4, voids existed in the transition zone of the three panels tested, which could have been due to the extreme severity of the treatment imposed on the materials. Besides, there was a significant increase of impregnation of hydrated cement products, especially CA, on the cell walls of the Pinus spp particles in the REF panels (Fig. 4a) and the SF30 panels (Fig. 4b). 
Table 10. Chemical Composition of the Pinus spp. Particles after 12 Months of Natural Weathering

\begin{tabular}{|c|c|c|c|c|c|}
\hline \multicolumn{2}{|c|}{ Chemical Element (\%) } & \multicolumn{2}{c|}{ Chemical Element (\%) } & \multicolumn{2}{c|}{ Chemical Element (\%) } \\
\hline $\mathrm{C}$ & 41.36 & $\mathrm{C}$ & 34.59 & $\mathrm{C}$ & 30.00 \\
\hline $\mathrm{O}$ & 49.18 & $\mathrm{O}$ & 50.33 & $\mathrm{O}$ & 52.70 \\
\hline $\mathrm{Mg}$ & - & $\mathrm{Mg}$ & - & $\mathrm{Mg}$ & 0.18 \\
\hline $\mathrm{Al}$ & - & $\mathrm{Al}$ & 2.19 & $\mathrm{Al}$ & 0.58 \\
\hline $\mathrm{Si}$ & 0.33 & $\mathrm{Si}$ & 3.93 & $\mathrm{Si}$ & 4.52 \\
\hline $\mathrm{S}$ & - & $\mathrm{S}$ & - & $\mathrm{S}$ & - \\
\hline $\mathrm{Cl}$ & 0.40 & $\mathrm{Cl}$ & - & $\mathrm{Cl}$ & - \\
\hline $\mathrm{K}$ & - & $\mathrm{K}$ & - & $\mathrm{K}$ & 0.41 \\
\hline $\mathrm{Ca}$ & 8.37 & $\mathrm{Ca}$ & 8.96 & $\mathrm{Ca}$ & 11.36 \\
\hline $\mathrm{Fe}$ & 0.29 & $\mathrm{Fe}$ & - & $\mathrm{Fe}$ & - \\
\hline Other & 0.07 & Other & - & Other & 0.25 \\
\hline Total & 100.00 & Total & 100.00 & Total & 100.00 \\
\hline
\end{tabular}

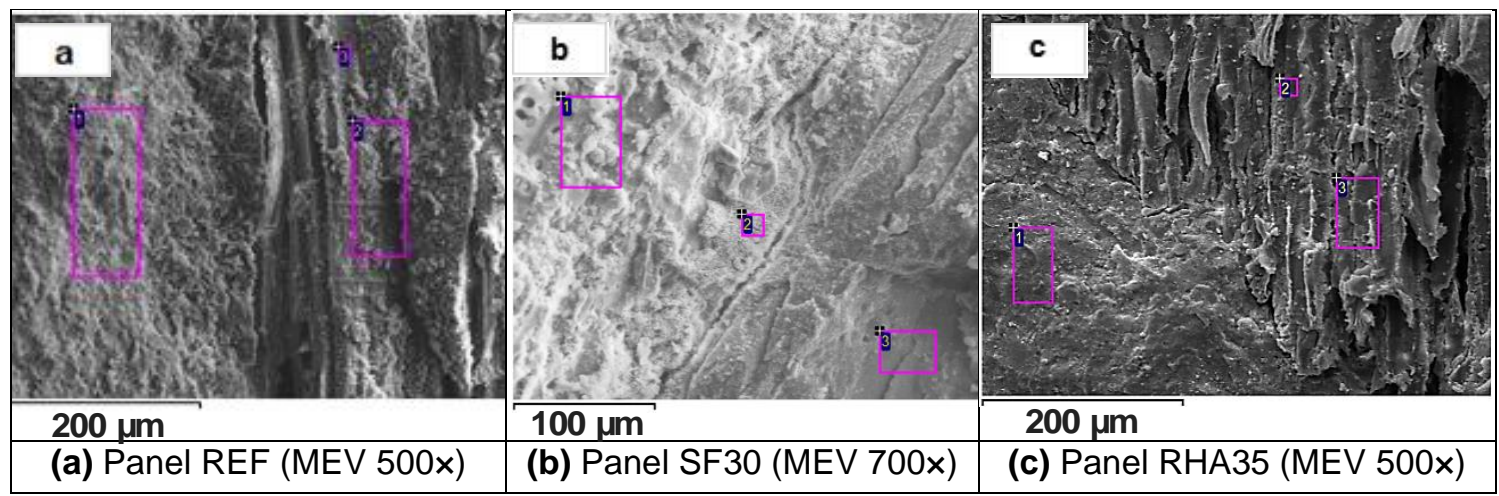

Fig. 4. Scanning electron micrographs and chemical composition of the Pinus spp. particles as determined by EDS after 40 cycles of accelerated weathering: (a) Panel REF, (b) Panel SF30, and (c) Panel RHA35. The boxes and numbers in the images refer to the EDS reading points.

Table 11. Chemical Composition of the Pinus spp. Particles after 40 Cycles of Accelerated Weathering

\begin{tabular}{|c|c|c|c|c|c|}
\hline \multicolumn{2}{|c|}{ Chemical Element (\%) } & \multicolumn{2}{c|}{ Chemical Element (\%) } & \multicolumn{2}{c|}{ Chemical Element (\%) } \\
\hline $\mathrm{C}$ & 39.02 & $\mathrm{C}$ & 15.30 & $\mathrm{C}$ & 42.99 \\
\hline $\mathrm{O}$ & 49.81 & $\mathrm{O}$ & 54.73 & $\mathrm{O}$ & 49.4 \\
\hline $\mathrm{Mg}$ & - & $\mathrm{Mg}$ & 0.45 & $\mathrm{Mg}$ & - \\
\hline $\mathrm{Al}$ & 0.25 & $\mathrm{Al}$ & 1.19 & $\mathrm{Al}$ & - \\
\hline $\mathrm{Si}$ & - & $\mathrm{Si}$ & 4.57 & $\mathrm{Si}$ & - \\
\hline $\mathrm{S}$ & 0.44 & $\mathrm{~S}$ & 2.30 & $\mathrm{~S}$ & - \\
\hline $\mathrm{Cl}$ & - & $\mathrm{Cl}$ & - & $\mathrm{Cl}$ & - \\
\hline $\mathrm{K}$ & - & $\mathrm{K}$ & - & $\mathrm{K}$ & - \\
\hline $\mathrm{Ca}$ & 10.48 & $\mathrm{Ca}$ & 20.78 & $\mathrm{Ca}$ & 7.67 \\
\hline $\mathrm{Fe}$ & - & $\mathrm{Fe}$ & - & $\mathrm{Fe}$ & - \\
\hline Other & - & Other & 0.68 & Other & - \\
\hline Total & 100.00 & Total & 100.00 & Total & 100.00 \\
\hline
\end{tabular}

De Lima et al. (2020). "Durable wood-cement panels," BioResources 15(2), 3064-3086. 3080 
The results of chemical analysis are summarized in Tables 9 to 11 . Effects of different levels of cement hydration products are compared, mainly $\mathrm{Ca}$, which migrated from the cement matrix to the interior of the wood particle cell walls. This migration is responsible for the mineralization of the wood.

\section{CONCLUSIONS}

1. The performance of Pinus spp. residue as a lignocellulosic aggregate in the development of wood cement panels was comparable to that obtained with other lignocellulosic residues.

2. The silica fume and rice husk ash were found to exhibit high levels of pozzolanic activity, and they could be used as partial substitutes in Portland cement while producing panels.

3. Approximately $99 \%$ of the used pine wood particles exhibited continuous size distribution, which ranged between 0.75 and $4.8 \mathrm{~mm}$.

4. No effect on the density of prepared panels either with the content of cement substitution and the type of weathering adopted in this study as revealed by the plots of density values as a function of the partial replacement of the cement by pozzolanas. Obtained density values for reference (REF) panels, silica fume (SF) panels, and rice husk ash (RHA)-35 were $1570 \mathrm{~kg} \cdot \mathrm{m}^{-3}, 1320 \mathrm{~kg} \cdot \mathrm{m}^{-3}, 1400 \mathrm{~kg} \cdot \mathrm{m}^{-3}$, respectively. All these values were lower than the recommended British standard values by $4.7 \%, 15.9 \%$, and $10.4 \%$ for REF, SF and RHA panels respectively.

5. No significant statistical difference was observed in swelling thickness of all prepared panels (REF, SF30, and RHA35) that were exposed to both natural weathering and accelerated weathering. Obtained values ranged between 0.20 to $0.23 \%$ for AW and 0.19 to $0.20 \%$ for natural weathering for AW5 panels. These values were well below the standard values shown by Bison panels.

6. Values of compressive strength (CS) of REF panels (27 MPa) and partially Portland cement substituted panels (SF 30 and RHA 35) increased initially during the AW cycles in general (Approx. 29 and $35 \mathrm{MPa}$ for SF30 and RHA 35, respectively). Later, they significantly decreased for all these panels for AW cycles (AW 10, AW 20, and AW 40). (Approx. 21 to $11 \mathrm{MPa}$ ).

7. Significant reductions in CS values were found for the three panels produced with REF panels showing CS losses of $21.48 \%$ at 5 AW cycles and $67.35 \%$ losses at 40 cycles. These panels showed the loss of $35.04 \%$ SC at 12 months of NW.

8. Reduction in the CS values of $30 \%$ SF and 35\% RHA containing panels showed $22.9 \%$ and $14.9 \%$, respectively after 28 days of curing in relation to the REF panels. On the other hand, at 40 cycles of accelerated weathering, the SF30 and RHA35 panels showed $30.2 \%$ and $35.0 \%$ higher CS values, respectively, than those of REF under the same conditions. After the natural weathering tests at 12 months, SF30 panels presented CS $7.80 \%$ higher than those determined for REF panels and RHA35 panels, CS values $18.0 \%$ lower than REF. Observing these values, and considering the highly deleterious 
effect of accelerated weathering assays, it can be concluded that the use of SF and RHA pozzolans improved the durability of the prototype panels produced.

9. Values of perpendicular tensile strength (IB) of all the three panels (1.3 to 0.9 MPa) studied in both natural weathering and accelerated weathering conditions were higher than the limit value $(0.40 \mathrm{MPa})$ indicated by the Bison Panel production process.

10. Value of modulus of rupture (MOR) of all the prepared panels (REF, SF30, and RHA35) was found to be approx. 2 to $6 \mathrm{MPa}$, which is lower than the minimum of 9 $\mathrm{MPa}$ indicated by the Bison Panel production process. These values showed a decreasing trend with weathering time in all three types of the prepared panels.

11. AW condition with different curing times showed their effect on MOR values of SF30 and RHA35 panels as revealed by the decreasing trend in their MOR values (approximately $1 \mathrm{MPa}$ to $0.6 \mathrm{MPa}$ ), while there was no effect of these parameters on the REF panels as revealed by the almost constant MOR value of these panels in both NW and AW condtions.

12. Values of modulus of elasticity (MOE) of REF, SF30, and RHA35 panels in AW conditions were in the range of 3 to $12 \mathrm{MPa}$, which was higher than the threshold value of $3 \mathrm{MPa}$ indicated by the Bison Panel production. However, the SF30 panels after 40 cycles of AW and the RHA35 panels after 12 months of NW did not follow this trend.

13. No constant direct correlation was observed between the values determined for the properties tested by the accelerated weathering and natural weathering tests. However, there was a large degradation of the panels after 20 cycles of the accelerated weathering, which was higher than the values observed after 12 months of natural weathering.

14. Morphology studies indicated particles of Pinus spp. were detached on SF30 panels after 12 months of natural weathering, while the same was observed in all the panels after 40 cycles of accelerated weathering.

15. No significant losses of the physical and/or mechanical properties of the panels produced with the pozzolanas were observed despite observed specific mass reductions. This was supported by the morphology studies where in no degradation of Pinus spp. was observed due to the alkalinity of the cementitious matrix.

\section{ACKNOWLEDGEMENTS}

The authors are grateful to the Laboratory of Chemistry of Wood of the Federal University of Paraná (UFPR), the Multiuser Center for Characterization of Materials (CMCM) of the Federal University of Technology of Paraná (UTFPR), and the Nucleus of Technological Research (NPT) of the UTFPR for their support in the characterization of the panels and component materials. They also would like to thank Prof. Anupama, Formerly Professor and Head, Department of Pharmaceutical Chemistry, Vivekananda College of Pharmacy, Bengaluru -560055 for her reading of the whole paper making necessary corrections in respect of English language and also suggestions to improve the quality of the paper. Dr. K. G. Satyanarayana would like to express his sincere thanks to 
the Poornaprajna Institute for Scientific Research (PPISR) in Bengaluru, Karnataka, India with whom he has been associated, for their encouragement.

\section{REFERENCES CITED}

ABNT NBR 7.215 (2019). “Cimento Portland - Determinação da resistência à compressão de corpos de prova cilíndricos [Portland cement - Determination of the compressive strength of cylindrical specimens]," Brazilian Association of Technical Standards, Rio de Janeiro, Brazil.

ABNT NBR 9.778 (2005). "Argamassa e concreto endurecidos: Determinação da absorção de água, índice de vazios e massa específica [Hardened mortar and concrete: Determination of water absorption, void index and specific mass]," Brazilian Association of Technical Standards, Rio de Janeiro, Brazil.

ABNT NBR 15.895 (2010). "Materiais pozolânicos - Determinação do teor de hidróxido de cálcio fixado - Método Chapelle modificado [Pozzolanic materials Determination of the fixed calcium hydroxide content - Modified Chapelle method]," Brazilian Association of Technical Standards, Rio de Janeiro, Brazil.

AFNOR NF P18-513 (2010). “Addition pour béton hydraulique - Métakaolin Spécifications et critères de conformité - Métakaolin, addition pouzzolanique pour bétons [Addition for hydraulic concrete - Metakaolin - Specifications and conformity criteria - Metakaolin, pozzolanic addition for concrete]," French Standardization Association, La Plaine Saint-Denis, France.

Ardanuy, M., Claramunt, J., and Filho, R. D. T. (2015). "Cellulosic fiber reinforced cement-based composites: A review of recent research," Construction and Building Materials 79, 115-128. DOI: 10.1016/j.conbuildmat.2015.01.035

ASTM C642 (2013). "Standard test method for density, absorption and voids in hardened concrete," ASTM International, West Conshohocken, PA, USA.

ASTM D1037 (2012). "Standard test methods for evaluating properties of wood-base fiber and particle panel materials," ASTM International, West Conshohocken, PA, USA.

Backlund, I., Arshadi, M., Hunt, A. J., McElroy, C. R., Attard, T. M., and Bergsten, U. (2014). "Extractive profiles of different lodgepole pine (Pinus contorta) fractions grown under a direct seeding-based silvicultural regime," Industrial Crops and Products 58, 220-229. DOI: 10.1016/j.indcrop.2014.04.027

Brazilian Metallurgical Industry (2015). Statistical Yearbook, Ministry of Mines and Energy, Brasília, Federal District, Brazil.

BSI EN 323 (1993). "Wood-based panels. Determination of density," British Standards Institution, London, England.

BSI EN 310 (1993). "Wood-based panels. Determination of modulus of elasticity in bending and of bending strength" British Standards Institution, London, England.

BSI EN 317 (1993). "Particleboards and fiberboards - Determination of swelling in thickness after immersion in water," British Standards Institution, London, England.

BSI EN 321 (2002). "Wood-based panels. Determination of moisture resistance under cyclic test conditions" British Standards Institution, London, England.

BSI EN 323 (1993). "Wood-based panels. Determination of density," British Standards Institution, London, England. 
CIDEM Hranice z.s. (2019). CETRIS Basic: Technical Data Sheet, Mesto, Czech Republic.

Claramunt, J., Ardanuy, M., and Fernandez-Carrasco, L. J. (2015). "Wet/dry cycling durability of cement mortar composites reinforced with micro and nanoscale cellulose pulps," BioResources 10(2), 3045-3055. DOI: 10.15376/biores.10.2.3045-3055

Dal Molin, D. C. C. (2005). "Adições minerais para concreto estrutural [Mineral additions to structural concrete," in: Concreto: Ensino, pesquisa e realizações [Concrete: Teaching, Research and Achievements], G. C. Isaia (ed.), IBRACON, São Paulo, Brazil, pp. 345-379.

Doudart de la Gree, G. C. H., Yu, Q. L., and Brouwers, H. J. H. (2014). "Wood-wool cement board: Utilization of a porous binder," in: $14^{\text {th }}$ International InorganicBonded Fiber Composites Conference, Da Nang, Vietnam, pp. 177-186.

Drochytka, R., and Petránek, V. (2007). "Environmental deterioration of building materials," in: Environmental Deterioration of Materials, A. Moncmanovà (ed.), Slovak Technical University, Slovakia, pp. 249-286.

EN 317 (1993). "Particleboards and fiberboards - Determination of swelling in thickness after immersion in water," European Committee for Standardization, Brussels, Belgium.

European Commission (EC) Directorate C (2002). "Commission Directorate C of 27 June 2002 general health and consumer protection - Scientific Opinions of the Scientific Committee on Toxicity, Ecotoxicity and the Environment," European Union, Brussels, Belgium.

Fan, M., Ndikontar, M. K., Zhou, X., and Ngamveng, J. N. (2012). “Cement-bonded composites made from tropical woods: Compatibility of wood and cement," Construction and Building Materials 36, 135-140. DOI: 10.1016/j.conbuildmat.2012.04.089

Fredriksson, M. (2010). Methods for Determination of Moisture Conditions in Wood Exposed to High Moisture Levels, Licentiate Thesis, Lund Institute of Technology, Lund, Scania, Sweden.

Gobbi, A. A. (2014). Atividade pozolânica de adições minerais pelas normas NBR 5751/2012 e NBR 5752/2012: Uma análise crítica a partir de métodos complementares [Pozzolanic Activity of Mineral Additions by the NBR 5751/2012 and NBR 5752/2012 Standards: A Critical Analysis Based on Complementary Methods], Master's Thesis, Federal University of Paraná, Curitiba, Brazil. (In Portuguese)

Hamdon, A. A. M. (2008). Effect of Some Treatments and Cement/wood ratio on the Quality of Mesquite (Prosopis chilensis) Wood cement Aggregates. Thesis of Master of Sciences Degree in Forestry, Department of Forest products and Industries, Faculty of Forestry, University of Khartoum, Sudan.

Hamouda, T., Seyam, A.-F. M., and Peters, K. (2015). "Evaluation of the integrity of 3D orthogonal woven composites with embedded polymer optical fibers," Composites Part B: Engineering 78, 79-85. DOI: 10.1016/j.compositesb.2015.03.092

Instituto Brasileiro de Geografia e Estatística (IBGE) (2017). "Indicadores conjunturais: Produção agrícola [Conjuncture indicators: Agricultural production]," Instituto Brasileiro de Geografia e Estatística [Brazilian Institute of Geography and Statistics], (http://www. ibge. gov.br), Accessed 24 Oct 2017. (In Portuguese)

Iwakiri, S., De Matos, J. L. M., Trianoski, R., and Prata, J. G. (2012). "Production of homogeneous and multilayer particleboard from Melia azedarach (Cinamomo) 
and Pinus taeda with different resin contents," Cerne 18(13), 465-470. DOI: 10.1590/S0104-77602012000300014

Lima, A. J. M., and Iwakiri, S. (2011). "Productos alternativos na produção de blocos para alvenaria estrutural [Alternative products in the production of structural masonry blocks]," Floresta e Ambiente [Forest and Environment] 18(3), 310-323. DOI: 10.4322/floram.2011.051

Macioski, G. (2017). Alkali-activation Study of Ceramic Blocks with Hydrated Lime, Master's Thesis, Federal Technological University of Paraná, Curitiba, Brazil.

Mehta, P. K., and Monteiro, P. J. M. (2013). Concrete: Microstructure, Properties, and Materials, McGraw Hill, New York, NY, USA.

Mohr, B. J. (2005). Durability of Pulp Fiber-Cement Composites, Ph.D. Dissertation, Georgia Institute of Technology, Atlanta, GA, USA.

National Congress of Brazil Computerized Legislation (LEI) 9055 (1995). "Computerized Legislation - LEI No 9055 of 1 June 1995 - Explanatory memorandum of the Chamber of Deputies," National Congress of Brazil, Brasília, Federal District, Brazil.

Nagarjuna Cement Ltd. (NCL) (2011). Product Guide: Bison Panel-Cement Bonded Particle Board, Nagarjuna Cement Ltd., Abids, Telangana, India.

Neville, A. M., and Brooks, J. J. (2013). Concrete Technology, Pearson Education, London, England.

Poonia, P. K., and Tripathi, S. (2018). "Effect of microwave heating on $\mathrm{pH}$ and termite resistance of Pinus roxburghii wood," Maderas. Ciencia y Tecnología 20(3), 499504. DOI: 10.4067/S0718-221X2018005031901

Sistema National de Informações Florestais (SNIF) (2016). "Produção Florestal [Forest production]," Sistema National de Informações Florestais [National Forest Information System], (http://www.florestal.gov.br), Acessed 16 Oct 2016. (In Portuguese)

Sruthi, V., and George, E. H. (2017). "A review on silica fume - An additive in concrete," International Journal of Innovative Research in Science 3(3), 274-281. DOI: 16.0415/IJARIIE-5009

Stark, N. M., Mathuna, L. M., and Clemons, C. M. (2004). "Effect of processing method on surface and weathering characteristics of wood-flour/HDPE composites," Journal of Applied Polymer Science 93(3), 1021-1030. DOI: 10.1002/app.20529

Tashima, M. M., Fioriti, C. F., Akasaki, J. L., Bernarbeu, J. P., Sousa, L. C., and Melges, J. L. P. (2012). "Highly reactive rice husk ash (CCA): Method of production and pozzolanic activity," Ambiente Construído [Built Environment] 12(2), 151-163. DOI: 10.1590/S1678-86212012000200010

TAPPI T204 cm-17 (2017). "Solvent extractives of wood and pulp," TAPPI Press, Atlanta, GA, USA.

TAPPI T252 om-16 (2016). " $\mathrm{pH}$ and electrical conductivity of hot water extracts of pulp, paper and paperboard," TAPPI Press, Atlanta, GA, USA.

Tichi, A. H., Bazyar, B., Khademieslan, H., Rangavar, H., and Talaeipour, M. (2016). "The effect of nano-wollastonite on biological, mechanical, physical and microstructural properties of the composite made of wood-cement fiber," Journal of Fundamental and Applied Sciences 8(3S), 1466-1479. DOI: 10.4314/jfas.v8i3s.285.

Vaickelionis, G., and Vaickelioniene, R. (2006). "Cement hydration in the presence of wood extractives and pozzolan mineral additives," Ceramics - Silikáty 50(2), 115122. 
Zanuncio, A. J. V., Carvalho, A. G., Souza, M. T., Jardim, C. M., Carneiro, A. C. O., and Colodette, J. L. (2015). "Effect of extractives on wood color of heat treated Pinus radiata and Eucalyptus pellita," Maderas. Ciencia y Tecnología 17(4), 857-864. DOI: 10.4067/S0718-221X2015005000074

Article submitted: June 8, 2019; Peer review completed: August 16, 2019; Revised version received: February 13, 2020; Accepted: February 17, 2020; Published: March 3, 2020.

DOI: 10.15376/biores.15.2.3064-3086 